\section{Hudsonian Chickadee}

By TONY CAPUSTEN, Prince Albert

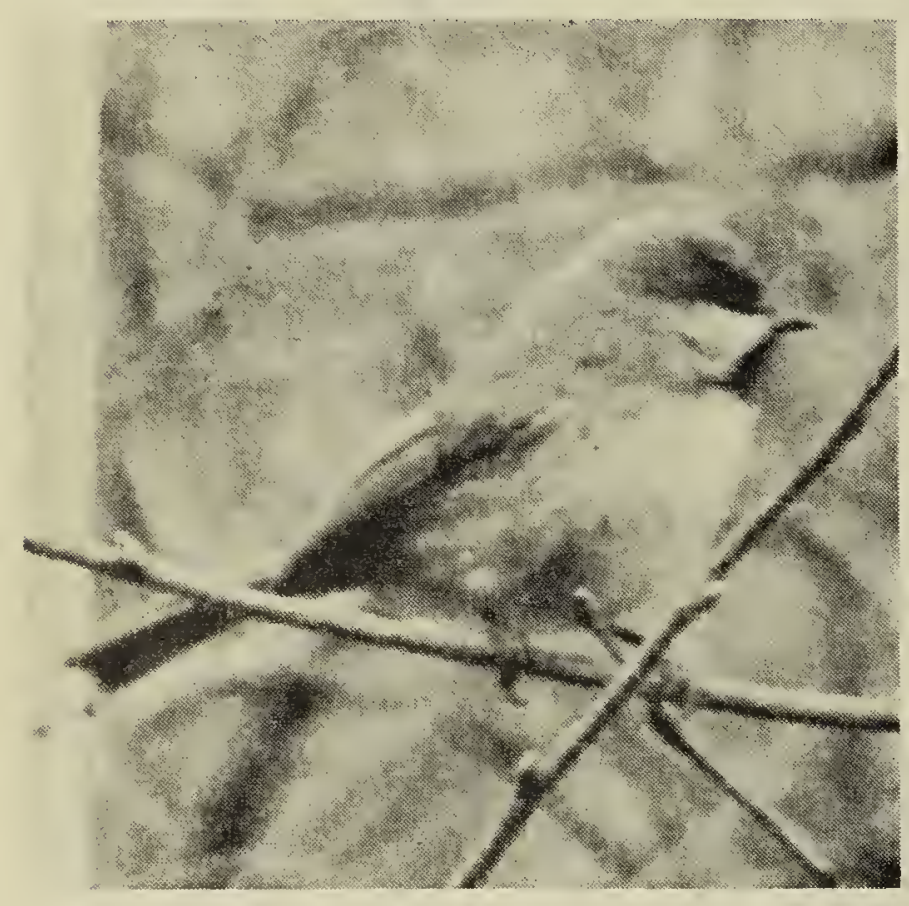

One day in May on the west side of Christies's Lake about three miles north of Prince Albert we saw a Hudsonian Chickadee hopping from branch to branch on a spruce tree and making querulous sounds.

After a few minutes it flew into a hole in a decayed birch stump and proceeded to carry out pieces of the soft pulpy wood to drop them some distance away.

The birch stump was located where the spruce swamp' merged with poplars at the foot of a sand ridge. It had broken off about fifteen feet above the ground and the entrance was about ten feet above the ground where the stump was about four or five inches in diameter.

After five or six trips it flew away. The excavation extended for about a foot down. Later in the season the bird completed its nest and laid eggs.

\section{PATTERNS OF JOY}

(Continued from page 27)

so many birds in full song even in July; everything gathering joy only to dispense it with prodigal hand as did our pioneers of long ago.

No need for Omar's "jug of wine, the loaf of bread" this golden year for the Prairie is a "Paradise enow".

\section{A Prairie Slouch}

\author{
By J. H. GRANT
}

All the long, hot day we travelled in the teeth of a chinook that sent tumble weeds bounding over the searing plain and whipped grass tops and weed seeds into our blistering faces - and at evening arrived at a tiny lake on the edge of the scrubland.

The red sun sank behind a hill and down with it went the wind. Air, cool, soothing and laden with the smell of water crept out from the slough which mirrored darkgreen clumps of choke-cherry bush and one patch of crimson sky. A pair of muskrats swam leisurely, leaving in their wake twin "v's" of tiny ripples. A robin sang from a silverberry bush, his inimitable liquid notes mingling with the murmur of the streamlet that fed the pond. From her nest on a cottonwood stump, a mourning dove crooned her plaintive lay, and from somewhere in the range lands beyond, faint and faraway came the lowing of cattle.

As dusk settled, the oxen, full-fed on the lush grasses of the lake shore, lay down by the wagon, drawing deep contented breaths and ruminating peacefully. We lay on the warm sand, the fresh vapor-laden air balm to our wind-chafed lips and nostrils, and the mellow gurgling call of the bittern lulling us to rest.

\section{THE SAPSUCKER}

(Continued from page 31 )

while Mom came in carrying him. He had fallen off the wall and was lying on the ground. He was so light we figured right away he was halfstarved. We got some warm milk, mixed syrup with it and tried to feed the sapsucker with an eyedropper. He wouldn't drink he just spit the milk back. We made the sapsucker as comfortable as we could.

Within about one hour our sapsucker was dead. I guess hunger had made him so tame. 